\title{
Synthesis and Anti-Cancer Activity Evaluation of Novel 1,3,4-Oxadiazole Substituted 5-Arylidene/Isatinylidene-2- Iminothiazolidiin-4-Ones
}

\author{
Maryan Lelyukh 1,*iD, Iryna Pylypchuk 2(D), Myroslava Kalytovska ${ }^{3} \mathbb{D}$, Stefan Harkov ${ }^{4}$ (D), Liubov \\ Kostyshyn 5 (i), Iryna Drapak 6 (iD)
}

1 Department of Pharmaceutical, Organic and Bioorganic Chemistry, Danylo Halytsky Lviv National Medical University, Pekarska 69, Lviv, 79010, Ukraine; lelyukh.m@gmail.com (M.L.);

2 Department of Obstetrics and Gynekology, Danylo Halytsky Lviv National Medical University, Pekarska 69, Lviv, 79010, Ukraine; iryna.pylypchuk@gmail.com (I.P.);

3 Department of Pharmacy and Biology, Stepan Gzhytskyi National University of Veterinary Medicine and Biotechnologies Lviv, Pekarska 50, Lviv, 79010, Ukraine; myroslava.kalytovska@gmail.com (M.K.);

4 Department of Pharmacy, Medical College of Burgas University “Prof. Dr. Asen Zlatarov”, St. Stambolov 69 Blv., Burgas, 8000, Bulgaria; stefan.harkov@mail.bg (S.H.);

5 Department of Toxicological and Analytical Chemistry, Danylo Halytsky Lviv National Medical University, 69 Pekarska, Lviv, 79010, Ukraine; kostyshynluba@gmail.com (L.K.);

6 Department of General, Bioinorganic, Physical and Colloidal Chemistry, Danylo Halytsky Lviv National Medical University, 69 Pekarska, Lviv, 79010, Ukraine; iradrapak@ukr.net (I.D.);

* Correspondence: lelyukh.m@gmail.com;

Scopus Author ID 57126452900

Received: 27.02.2021; Revised: 6.04.2021; Accepted: 10.04.2021; Published: 26.04.2021

\begin{abstract}
Following the interaction of 2-chloro- $N$-(5-aryl-1,3,4-oxadiazole-2-yl) acetamides 1a-b with ammonium thiocyanate in dry acetone, the 5-unsubstituted 2-imino-4-thiazolidinones 4a-b have been synthesized. Compounds 4a-b were subsequently utilized in Knoevenagel condensation with aromatic aldehydes or isatin derivatives to synthesize the series of 5-arylidene/isatinylidene substituted 2-(1,3,4oxadiazol-2-yl)imino-4-thiazolidinones 5a-h and 6a-d. The structures of target compounds were confirmed by using ${ }^{1} \mathrm{H}$ NMR spectroscopy and elemental analysis. Evaluation of anti-cancer activity in vitro for the synthesized compounds was performed following the National Cancer Institute protocol against leukemia, melanoma, lung, colon, CNS, ovarian, renal, prostate, and breast cancer cell lines. As a result, the most active compound 5a, namely 2-[5-(4-chlorophenyl)-[1,3,4]oxadiazol-2-ylimino]-5(4-methoxybenzylidene)thiazolidin-4-one was found to be a highly efficient anti-tumor candidate with average $\log \mathrm{GI}_{50}$ and $\log \mathrm{TGI}$ values of -5.19 and -4.09 , respectively.
\end{abstract}

Keywords: organic synthesis; 2-iminothiazolidine-4-ones; 1,3,4-oxadiazoles; amino-imino tautomerism; E/Z-isomerism; anti-cancer activity.

(C) 2021 by the authors. This article is an open-access article distributed under the terms and conditions of the Creative Commons Attribution (CC BY) license (https://creativecommons.org/licenses/by/4.0/).

\section{Introduction}

4-Thiazolidinone core belongs to efficient and important heterocyclic construction motifs to develop novel highly active molecules in modern bioorganic and medicinal chemistry [1-4]. An important class with a proven broad pharmacological profile among functionally substituted 4-thiazolidinones is a narrower chemical group - 2-imino derivatives presenting a diverse range of biological activities such as anti-cancer [5-7], antifungal [8, 9], antimicrobial [9, 10], anti-inflammatory [11, 12], antinociceptive [13], antiamoebic [14], free-radical scavenging [13] action etc. It was found that the anti-tumor properties of 5-ylidene substituted 
2-imino-4-thiazolidinones can be expressed through different mechanisms featuring the affinity towards antiproliferation bio targets such as nonmembranous protein tyrosine phosphatase I [15], cyclin-dependent kinase CDK2 II [16], phosphatase of a regenerating liver PRL-3 III [17], tubulin polymerization IV [18] (Fig. 1).

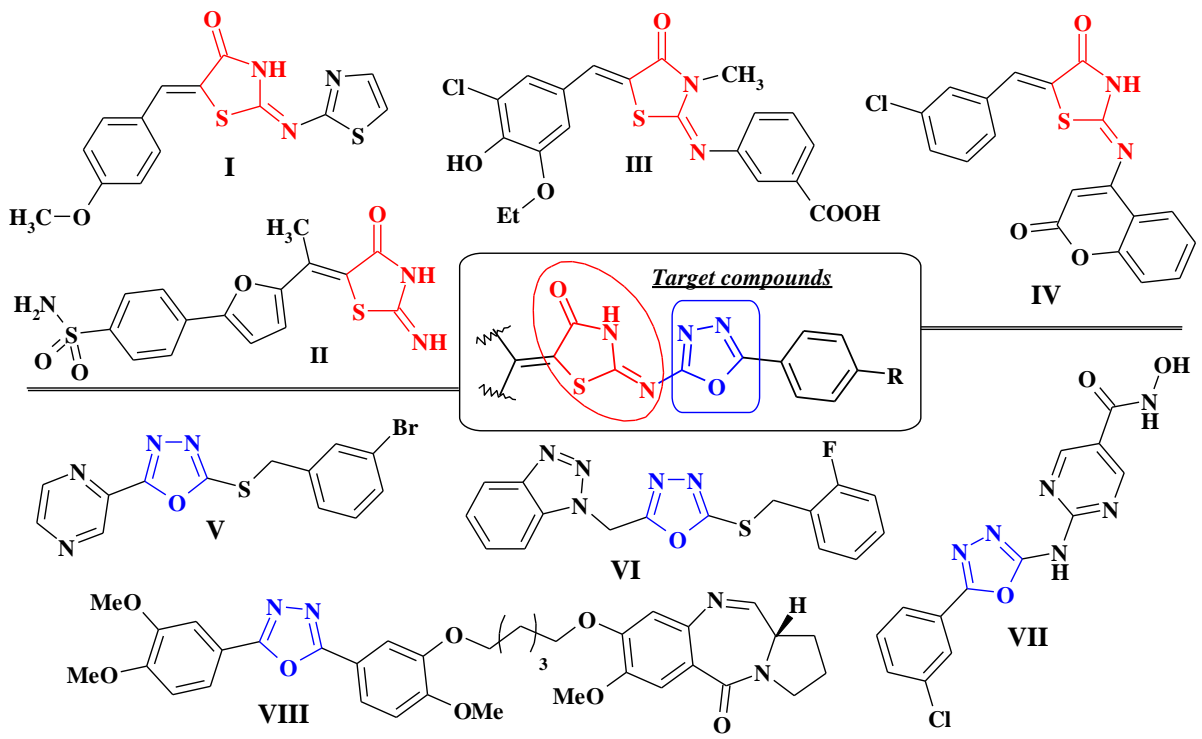

Figure 1. Structures of 5-ylidene substituted 2-iminothiazolidine-4-ones and 2,5-disubstituted 1,3,4-oxadiazoles with promising anti-tumor potential.

On the other hand, 1,3,4-oxadiazole derivatives have been known to possess a broad spectrum of biological activity [19-25]. The chemical features of 1,3,4-oxadiazoles were described in numerous reviews focusing on the main approaches to the synthesis, modification, and pharmacological potential [26-30]. It belongs to the privileged scaffolds in modern medicinal chemistry, including anti-cancer profile [31,32] due to their inhibitory impact on telomerase V [33], focal adhesion kinase VI [34], and histone deacetylase VII [35], as well as mitochondrial-mediated apoptosis-inducing ability VIII [36] (Fig. 1).

Therefore, based on the conception of the molecular hybridization approach, the conjugation of 2-imino-4-thiazolidinone template with 1,3,4-oxadiazole cycles can be considered a prospective approach for drug-like molecules build-up. Considering that various 4-thiazolidinone based hybrid molecules bearing 1,3,4-oxadiazole or relative 1,3,4-thiadiazole heterocyclic systems have shown synergistic effect in many cases [37-40], we designed and synthesized a new series of novel 2-(5-aryl-1,3,4-oxadiazole-2-yl) substituted 5-ylidene-2iminothiazolidin-4-ones for screening theirs in vitro anti-cancer activity.

\section{Materials and Methods}

\subsection{Materials.}

The starting 2-amino-5-aryl-[1,3,4] oxadiazoles were obtained according to known methodologies [41]. All reagents and solvents were commercially available and of analytical grade used without further purification and drying.

\subsection{Chemistry.}

The melting points were determined on a NAGEMA-K8 polarization microscope equipped with a Boetius heating stage using a digital thermometer, «Ama-digit ad 14 th» and are uncorrected. The ${ }^{1} \mathrm{H}$ NMR spectra were recorded on Varian Gemini $400 \mathrm{MHz}$ in DMSO- 
$d_{6}+\mathrm{CCl}_{4}$ mixture. Chemical shifts are reported as $\delta(\mathrm{ppm})$ relative to tetramethylsilane as an internal standard, coupling constant $J$ are expressed in $\mathrm{Hz}$. The experimental data of elemental analysis on a contest of carbon, hydrogen and nitrogen were performed using the Perkin-Elmer $2400 \mathrm{CHN}$ analyzer and amounted to $\pm 0.4 \%$ of the theoretical values.

2.2.1. General procedure for the preparation of 5-unsubstituted 2-(5-aryl-[1,3,4]oxadiazol-2ylimino)thiazolidin-4-ones (4a-b).

A mixture of corresponding 2-chloro-N-(5-aryl-[1,3,4]oxadiazol-2-yl)acetamide 1a or $1 \mathrm{~b}(10 \mathrm{mmol})$ and ammonium thiocyanate $(20 \mathrm{mmol})$ was heated under the reflux for $8 \mathrm{~h}$ in dry acetone $(20 \mathrm{ml})$. After cooling to room temperature, the precipitate was filtered off, washed with water and ethanol, dried, and recrystallized with DMF:ethanol (1:2) mixture.

2-[5-(4-Chlorophenyl)-[1,3,4]oxadiazol-2-ylimino]thiazolidin-4-one (4a). Yield 80\%; $\mathrm{mp}=273-274{ }^{\circ} \mathrm{C} .{ }^{1} \mathrm{H}$ NMR $\left(400 \mathrm{MHz}, \mathrm{DMSO}-\mathrm{d}_{6}+\mathrm{CCl}_{4}\right): \delta_{\mathrm{H}}[\mathrm{ppm}]=12.53$ (brs, $1 \mathrm{H}, \mathrm{NH}-$ thiaz), 7.95 (d, J = 8.5 Hz, 2H, Ar), 7.65 (d, J = 8.5 Hz, 2H, Ar), 4.16 (s, 2H, $\mathrm{CH}_{2}$-thiaz). Calcd for $\mathrm{C}_{11} \mathrm{H}_{7} \mathrm{ClN}_{4} \mathrm{O}_{2} \mathrm{~S}: \mathrm{C}, 44.83 ; \mathrm{H}, 2.39 ; \mathrm{N}, 19.01$. Found: C, 45.02; H, 2.47; N, 19.24.

2-[5-(4-Methoxyphenyl)-[1,3,4]oxadiazol-2-ylimino]thiazolidin-4-one (4b). Spectral and analytical data are described previously [42].

2.2.2. General procedure for the preparation of 5-arylidene-2-(5-aryl-[1,3,4]oxadiazol-2ylimino)thiazolidin-4-ones (5a-h).

A mixture of compounds $4 \mathrm{a}$ or $4 \mathrm{~b}(3 \mathrm{mmol})$, appropriate aldehyde $(4 \mathrm{mmol})$, and anhydrous sodium acetate $(3 \mathrm{mmol})$ was refluxed for $4 \mathrm{~h}$ in glacial acetic acid $(20 \mathrm{ml})$. The powder obtained after cooling was filtered off, washed with acetic acid, water, and methanol, dried, and recrystallized with DMF:acetic acid (1:2) mixture.

2-[5-(4-Chlorophenyl)-[1,3,4]oxadiazol-2-ylimino]-5-(4-methoxybenzylidene)thiazolidin-4-one (5a). Yield 67\%; $\mathrm{mp}=259-260^{\circ} \mathrm{C} .{ }^{1} \mathrm{H}$ NMR (400 MHz, DMSO-d $\left.+\mathrm{CCl}_{4}\right)$ : $\delta_{\mathrm{H}}[\mathrm{ppm}]=13.03$ (brs, 1H, NH-thiaz), 7.96 (d, J = 7.8 Hz, 2H, Ar), 7.77 (s, 1H, Ar-CH=), 7.64 $(\mathrm{d}, \mathrm{J}=7.5 \mathrm{~Hz}, 4 \mathrm{H}, \mathrm{Ar}), 7.16(\mathrm{~d}, \mathrm{~J}=7.8 \mathrm{~Hz}, 2 \mathrm{H}, \mathrm{Ar}), 3.84\left(\mathrm{~s}, 3 \mathrm{H}, \mathrm{OCH}_{3}\right)$. Calcd for $\mathrm{C}_{19} \mathrm{H}_{13} \mathrm{ClN}_{4} \mathrm{O}_{3} \mathrm{~S}: \mathrm{C}, 55.28 ; \mathrm{H}, 3.17 ; \mathrm{N}, 13.57$. Found: C, 55.42; H, 3.29; N, 13.49.

2-[5-(4-Chlorophenyl)-[1,3,4]oxadiazol-2-ylimino]-5-(4-dimethylaminobenzylidene)thiazolidin-4-one (5b). Yield 72\%; mp 283-284 ${ }^{\circ} \mathrm{C} .{ }^{1} \mathrm{H}$ NMR (400 MHz, DMSO-d $\left.6+\mathrm{CCl}_{4}\right): \delta \mathrm{H}$ $[\mathrm{ppm}]=12.83$ (brs, 1H, NH-thiaz), $7.95(\mathrm{~d}, \mathrm{~J}=8.4 \mathrm{~Hz}, 2 \mathrm{H}, \mathrm{Ar}), 7.67-7.63$ (m, 3H, Ar+Ar$\mathrm{CH}=), 7.50(\mathrm{~d}, \mathrm{~J}=8.7 \mathrm{~Hz}, 2 \mathrm{H}, \mathrm{Ar}), 6.86(\mathrm{~d}, \mathrm{~J}=8.7 \mathrm{~Hz}, 2 \mathrm{H}, \mathrm{Ar}), 3.03\left(\mathrm{~s}, 6 \mathrm{H}, \mathrm{N}\left(\mathrm{CH}_{3}\right)_{2}\right)$. Calcd for $\mathrm{C}_{20} \mathrm{H}_{16} \mathrm{ClN}_{5} \mathrm{O}_{2} \mathrm{~S}$ : C, 56.40; H, 3.79; N, 16.44. Found: C, 56.54; H, 3.92 N, 16.53.

2-[5-(4-Chlorophenyl)-[1,3,4]oxadiazol-2-ylimino]-5-(4-hydroxy-3-methoxybenzylidene)thiazolidin-4-one (5c). Yield 68\%; mp 277-278 ${ }^{\circ} \mathrm{C} .{ }^{1} \mathrm{H}$ NMR (400 MHz, DMSO$\left.\mathrm{d}_{6}+\mathrm{CCl}_{4}\right): \delta_{\mathrm{H}}[\mathrm{ppm}]=12.89$ (brs, 1H, NH-thiaz), $9.76(\mathrm{~s}, 1 \mathrm{H}, \mathrm{OH}), 7.97$ (d, J = 7.8 Hz, 2H, Ar), 7.69 (s, 1H, Ar-CH=), 7.56 (d, J = 7.9 Hz, 2H, Ar), 7.17-7.12 (m, 2H, Ar), 6.97 (d, J = 7.5 $\mathrm{Hz}, 1 \mathrm{H}, \mathrm{Ar}), 3.89$ (s, 3H, OCH 3$)$. Calcd for $\mathrm{C}_{19} \mathrm{H}_{13} \mathrm{ClN}_{4} \mathrm{O}_{4} \mathrm{~S}: \mathrm{C}, 53.21 ; \mathrm{H}, 3.06 ; \mathrm{N}, 13.06$. Found: C, 53.34; H, $3.17 \mathrm{~N}, 13.19$.

2-[5-(4-Methoxyphenyl)-[1,3,4] oxadiazol-2-ylimino]-5-(4-chlorobenzylidene)thiazolidin-4-one (5d). Yield 75\%; $\mathrm{mp}=304-305^{\circ} \mathrm{C} .{ }^{1} \mathrm{H}$ NMR (400 MHz, DMSO-d6+CCl 4$)$ : $\delta_{\mathrm{H}}[\mathrm{ppm}]=7.91(\mathrm{~d}, \mathrm{~J}=8.6 \mathrm{~Hz}, 2 \mathrm{H}, \mathrm{Ar}), 7.79(\mathrm{~s}, 1 \mathrm{H}, \mathrm{Ar}-\mathrm{CH}=), 7.69(\mathrm{~d}, \mathrm{~J}=8.5 \mathrm{~Hz}, 2 \mathrm{H}, \mathrm{Ar})$, $7.64(\mathrm{~d}, \mathrm{~J}=8.4 \mathrm{~Hz}, 2 \mathrm{H}, \mathrm{Ar}), 7.13(\mathrm{~d}, \mathrm{~J}=8.7 \mathrm{~Hz}, 2 \mathrm{H}, \mathrm{Ar}), 3.86\left(\mathrm{~s}, 3 \mathrm{H}, \mathrm{OCH}_{3}\right)$. Calcd for $\mathrm{C}_{19} \mathrm{H}_{13} \mathrm{ClN}_{4} \mathrm{O}_{3} \mathrm{~S}$ : C, 55.28; H, 3.17; N, 13.57. Found: C, 55.19; H, 3.26; N, 13.68 . 
2-[5-(4-Methoxyphenyl)-[1,3,4]oxadiazol-2-ylimino]-5-(4-methoxybenzylidene)thiazolidin-4-one (5e). Yield 69\%; mp = 276-277 ${ }^{\circ}$. ${ }^{1} \mathrm{H}$ NMR (400 MHz, DMSO-d6+CCl 4$)$ : $\delta \mathrm{H}[\mathrm{ppm}]=12.96$ (brs, 1H, NH-thiaz), 7.90 (d, J = 8.8 Hz, 2H, Ar), 7.77 (s, 1H, Ar-CH=), 7.65 $(\mathrm{d}, \mathrm{J}=8.7 \mathrm{~Hz}, 2 \mathrm{H}, \mathrm{Ar}), 7.17-7.12(\mathrm{~m}, 4 \mathrm{H}, \mathrm{Ar}), 3.85\left(\mathrm{~s}, 6 \mathrm{H}, 2^{*} \mathrm{OCH}_{3}\right)$. Calcd for $\mathrm{C}_{20} \mathrm{H}_{16} \mathrm{~N}_{4} \mathrm{O}_{4} \mathrm{~S}$ : C, 58.81; H, 3.95; N, 13.72. Found: C, 58.96; H, 4.06; N, 13.84 .

2-[5-(4-Methoxyphenyl)-[1,3,4]oxadiazol-2-ylimino]-5-(4-dimethylaminobenzylidene)-thiazolidin-4-one (5f). Spectral and analytical data are described previously [42].

2-[5-(4-Methoxyphenyl)-[1,3,4]oxadiazol-2-ylimino]-5-(4-hydroxy-3-methoxybenzylidene)thiazolidin-4-one (5g). Yield $72 \%$; $\mathrm{mp}=277-278^{\circ} \mathrm{C} .{ }^{1} \mathrm{H}$ NMR $(400 \mathrm{MHz}$, DMSO-d $\left.{ }_{6}+\mathrm{CCl}_{4}\right): \delta_{\mathrm{H}}[\mathrm{ppm}]=12.83$ (brs, $1 \mathrm{H}, \mathrm{NH}$-thiaz), 9.77 (brs, $\left.1 \mathrm{H}, \mathrm{OH}\right), 7.89(\mathrm{~d}, \mathrm{~J}=8.4$ $\mathrm{Hz}, 2 \mathrm{H}, \mathrm{Ar}), 7.76$ (s, 1H, Ar-CH=), 7.18 (s, 1H, Ar), 7.13 (d, J = 8.1 Hz, 1H, Ar), 7.05 (d, J = $8.3 \mathrm{~Hz}, 2 \mathrm{H}, \mathrm{Ar}), 6.97(\mathrm{~d}, \mathrm{~J}=8.1 \mathrm{~Hz}, 1 \mathrm{H}, \mathrm{Ar}), 3.86,3.89\left(2 \mathrm{~s}, 6 \mathrm{H}, 2 * \mathrm{OCH}_{3}\right)$. Calcd for $\mathrm{C}_{20} \mathrm{H}_{16} \mathrm{~N}_{4} \mathrm{O}_{5} \mathrm{~S}$ : C, 56.60; H, 3.80; N, 13.20. Found: C, 56.81; H, 3.93; N, 13.34 .

2-[5-(4-Methoxyphenyl)-[1,3,4]oxadiazol-2-ylimino]-5-(3,4-dimethoxybenzylidene)thiazolidin-4-one (5h). Yield 69\%; $\mathrm{mp}=250-251{ }^{\circ} \mathrm{C} .{ }^{1} \mathrm{H}$ NMR $\left(400 \mathrm{MHz}, \mathrm{DMSO}-\mathrm{d}_{6}+\mathrm{CCl}_{4}\right)$ : $\delta_{\mathrm{H}}[\mathrm{ppm}]=13.00$ (brs, 1H, NH-thiaz), 7.89 (d, J = 8.6 Hz, 2H, Ar), 7.76 (s, 1H, Ar-CH=), 7.28-7.26 (m, 2H, Ar), 7.20 (d, J = 8.8 Hz, 1H, Ar), 7.12 (d, J = 8.7 Hz, 2H, Ar), 3.85 (s, 9H, $\left.3 * \mathrm{OCH}_{3}\right)$. Calcd for $\mathrm{C}_{21} \mathrm{H}_{18} \mathrm{~N}_{4} \mathrm{O}_{5} \mathrm{~S}: \mathrm{C}, 57.53 ; \mathrm{H}, 4.14 ; \mathrm{N}, 12.78$. Found: C, 57.39; H, 4.28; N, 12.91.

2.2.3. General procedure for the preparation of 5-isatinylidene-2-(5-aryl-[1,3,4]oxadiazol-2ylimino)thiazolidin-4-ones (6a-d).

A mixture of compounds $4 \mathrm{a}$ or $4 \mathrm{~b}(3 \mathrm{mmol})$, isatin or 5 -chloroisatin $(4 \mathrm{mmol})$, and anhydrous sodium acetate $(3 \mathrm{mmol})$ in glacial acetic acid $(20 \mathrm{ml})$ was heated under the reflux for $4 \mathrm{~h}$. The reaction mixture was cooled to room temperature; the obtained precipitate was filtered off, washed with acetic acid, water, and methanol, dried, and recrystallized with DMF:acetic acid (1:2) mixture.

2-[5-(4-Chlorophenyl)-[1,3,4]oxadiazol-2-ylimino]-5-(2-oxo-1,3-dihydroindol-3ylidene)thiazolidin-4-one (6a). Yield 76\%; $\mathrm{mp}>320^{\circ} \mathrm{C}$. ${ }^{1} \mathrm{H}$ NMR (400 MHz, DMSO-d $6+\mathrm{CCl}_{4}$ ): $\delta_{\mathrm{H}}[\mathrm{ppm}]=11.09$ (brs, $1 \mathrm{H}, \mathrm{NH}$, isatin), $8.81(\mathrm{~d}, \mathrm{~J}=7.9 \mathrm{~Hz}, 1 \mathrm{H}$, isatin), $7.97(\mathrm{~d}, \mathrm{~J}=8.2 \mathrm{~Hz}, 2 \mathrm{H}$, Ar), $7.63(\mathrm{~d}, \mathrm{~J}=8.4 \mathrm{~Hz}, 2 \mathrm{H}, \mathrm{Ar}), 7.37$ (t, $\mathrm{J}=7.4 \mathrm{~Hz}, 1 \mathrm{H}$, isatin), 7.07 (t, J = 8.1 Hz, 1H, isatin), $6.94\left(\mathrm{~d}, \mathrm{~J}=7.5 \mathrm{~Hz}, 1 \mathrm{H}\right.$, isatin). Calcd for $\mathrm{C}_{19} \mathrm{H}_{10} \mathrm{ClN}_{5} \mathrm{O}_{3} \mathrm{~S}: \mathrm{C}, 53.84 ; \mathrm{H}, 2.38 ; \mathrm{N}, 16.52$. Found: C, 54.03; H, 2.46; N, 16.43.

2-[5-(4-Chlorophenyl)-[1,3,4] oxadiazol-2-ylimino]-5-(5-chloro-2-oxo-1,3dihydroindol-3-ylidene)thiazolidin-4-one (6b). Yield 73\%; mp >320 ${ }^{\circ}$. ${ }^{1} \mathrm{H}$ NMR $(400 \mathrm{MHz}$, DMSO-d $\left.6+\mathrm{CCl}_{4}\right): \delta_{\mathrm{H}}[\mathrm{ppm}]=11.26(\mathrm{~s}, 1 \mathrm{H}, \mathrm{NH}$, isatin), $8.81(\mathrm{~s}, 1 \mathrm{H}$, isatin), $7.94(\mathrm{~d}, \mathrm{~J}=7.9 \mathrm{~Hz}$, 2H, Ar), 7.62 (d, J = 7.8 Hz, 2H, Ar), 7.39 (d, J = 8.0 Hz, 1H, isatin), $6.93(\mathrm{~d}, \mathrm{~J}=7.8 \mathrm{~Hz}, 1 \mathrm{H}$, isatin). Calcd for $\mathrm{C}_{19} \mathrm{H}_{9} \mathrm{Cl}_{2} \mathrm{~N}_{5} \mathrm{O}_{3} \mathrm{~S}: \mathrm{C}, 49.80 ; \mathrm{H}, 1.98 ; \mathrm{N}, 15.28$. Found: C, 50.03; H, 2.11; N, 15.43 .

2-[5-(4-Methoxyphenyl)-[1,3,4] oxadiazol-2-ylimino]-5-(2-oxo-1,3-dihydroindol-3ylidene)thiazolidin-4-one (6c). Yield 75\%; $\mathrm{mp}=317-318^{\circ} \mathrm{C} .{ }^{1} \mathrm{H}$ NMR (400 MHz, DMSO$\left.\mathrm{d}_{6}+\mathrm{CCl}_{4}\right): \delta_{\mathrm{H}}[\mathrm{ppm}]=13.18$ (brs, $1 \mathrm{H}, \mathrm{NH}$-thiaz), $11.13(\mathrm{~s}, 1 \mathrm{H}, \mathrm{NH}$, isatin), $8.81(\mathrm{~d}, \mathrm{~J}=7.8 \mathrm{~Hz}$, $1 \mathrm{H}$, isatin), $7.90(\mathrm{~d}, \mathrm{~J}=8.4 \mathrm{~Hz}, 2 \mathrm{H}, \mathrm{Ar}), 7.38(\mathrm{t}, \mathrm{J}=7.6 \mathrm{~Hz}, 1 \mathrm{H}$, isatin), $7.12(\mathrm{~d}, \mathrm{~J}=8.4 \mathrm{~Hz}, 2 \mathrm{H}$, Ar), 7.05 (t, $\mathrm{J}=7.7 \mathrm{~Hz}, 1 \mathrm{H}$, isatin), $6.94\left(\mathrm{~d}, \mathrm{~J}=7.7 \mathrm{~Hz}, 1 \mathrm{H}\right.$, isatin), 3.84 (s, 3H, $\mathrm{OCH}_{3}$ ). Calcd for $\mathrm{C}_{20} \mathrm{H}_{13} \mathrm{~N}_{5} \mathrm{O}_{4} \mathrm{~S}$ : C, 57.27; H, 3.12; N, 16.70. Found: C, 57.43; H, 3.19; N, 16.57. 
2-[5-(4-Methoxyphenyl)-[1,3,4] oxadiazol-2-ylimino]-5-(5-chloro-2-oxo-1,3dihydroindol-3-ylidene)thiazolidin-4-one (6d). Yield 74\%; $\mathrm{mp}>320^{\circ} \mathrm{C}$. ${ }^{1} \mathrm{H}$ NMR $(400 \mathrm{MHz}$, DMSO-d $\left.6+\mathrm{CCl}_{4}\right): \delta_{\mathrm{H}}[\mathrm{ppm}]=13.25$ (brs, $1 \mathrm{H}, \mathrm{NH}$-thiaz), $11.28(\mathrm{~s}, 1 \mathrm{H}, \mathrm{NH}$, isatin), $8.82(\mathrm{~s}, 1 \mathrm{H}$, isatin), $7.87(\mathrm{~d}, \mathrm{~J}=8.6 \mathrm{~Hz}, 2 \mathrm{H}, \mathrm{Ar}), 7.40(\mathrm{~d}, \mathrm{~J}=7.9 \mathrm{~Hz}, 1 \mathrm{H}$, isatin), $7.09(\mathrm{~d}, \mathrm{~J}=8.6 \mathrm{~Hz}, 2 \mathrm{H}$, $\mathrm{Ar}), 6.93\left(\mathrm{~d}, \mathrm{~J}=8.3 \mathrm{~Hz}, 1 \mathrm{H}\right.$, isatin), $3.83\left(\mathrm{~s}, 3 \mathrm{H}, \mathrm{OCH}_{3}\right)$. Calcd for $\mathrm{C}_{20} \mathrm{H}_{12} \mathrm{ClN}_{5} \mathrm{O}_{4} \mathrm{~S}: \mathrm{C}, 52.93$; H, 2.67; N, 15.43. Found: C, 53.12; H, 2.79; N, 15.58 .

\subsection{Biology (anti-cancer activity against 60 human tumor cell lines).}

The anti-cancer activity of tested compounds was determined by the sulforhodamine B assay on a panel of approximately 60 human tumor cell lines in accordance with the protocol of the Drug Evaluation Branch, National Cancer Institute (NCI), Bethesda (www.dtp.nci.nih.gov). To the culture of corresponding cell lines, the tested compounds at a single concentration $\left(10^{-5} \mathrm{M}\right)$ were added, and the cultures were incubated for $48 \mathrm{~h}$. The growth percent for each tested compound was determined spectrophotometrically with a proteinbinding dye, sulforhodamine B (SRB) compared to the control cells not treated with the test agents. Compounds that exhibited significant growth inhibition were evaluated in vitro against the 60 human tumor cell lines panel at five concentration levels ranging from $10^{-4}$ to $10^{-8} \mathrm{M}$. To estimate cell viability or growth, the 48-h continuous drug exposure protocol was used based on SRB protein assay was used, as described previously [43-46].

Using the seven absorbance measurements, the percent growth inhibition was calculated at each of the drug concentrations levels using the following formula:

$$
\begin{gathered}
{[(\mathrm{Ti}-\mathrm{Tz}) /(\mathrm{C}-\mathrm{Tz})] \times 100 \text { for concentrations for which } \mathrm{Ti} \geq \mathrm{Tz}} \\
{[(\mathrm{Ti}-\mathrm{Tz}) / \mathrm{Tz}] \times 100 \text { for concentrations for which } \mathrm{Ti}<\mathrm{Tz} .}
\end{gathered}
$$

For compounds that showed the highest anti-cancer activity, three dose-response parameters (GI50, TGI, LC 50 ) were calculated. In particular, GI50 value is interpreted as the drug concentration resulting in a 50\% lower net protein increase in the treated cells as compared to the net protein increase seen in the control cells. It was calculated from formula $[(\mathrm{Ti}-\mathrm{Tz}) /(\mathrm{C}$ $-\mathrm{Tz})] \times 100-50$. TGI value indicates the concentration that caused total growth inhibition and calculated from $\mathrm{Ti}=\mathrm{Tz}$. The $\mathrm{LC}_{50}$ means the concentration of the drug resulting in a 50\% reduction in the measured protein at the end of the drug treatment as compared to that at the beginning. The $\mathrm{LC}_{50}$ indicating a net loss of cells following treatment was calculated from [(Ti $-\mathrm{Tz}) / \mathrm{Tz}] \times 100=-50$. Values were calculated for each of these three parameters if the level of activity was reached. The $\log \mathrm{GI}_{50}, \log \mathrm{TGI}, \operatorname{logLC_{50}}$ were then determined, defined as the mean of the log's of the individual GI50, TGI and LC 50 values. The lowest values are obtained with the most sensitive cell lines. Compounds having these values $\leq 4$ were declared to be active.

\section{Results and Discussion}

\subsection{Chemistry.}

Following the reaction of 2-amino-5-aryl-1,3,4-oxadiazoles with chloroacetyl chloride in dioxane medium, the corresponding 2-chloro- $N$-(1,3,4-oxadiazol-2-yl)acedamides $1 \mathrm{a}-\mathrm{b}$ were obtained. Further interaction of $1 \mathrm{a}-\mathrm{b}$ with ammonium thiocyanate in dry acetone occurs as a nucleophilic substitution of chlorine atom by thiocyanate group and results in the formation of intermediates $2 a-b$. Then $2 a-b$ undergoes spontaneous cyclization (3a-b), accompanied by 
migration of the oxadiazole substituent from the cyclic nitrogen atom to the exocyclic one (Dimroth rearrangement). Using this procedure, the synthesis of novel 2-iminothiazolidine-4one derivatives containing 1,3,4-oxadiazole moiety 4a-b was performed. Further chemical modification of the obtained oxadiazolyl-iminothiazolidinones 4a-b was carried out by interaction with aromatic aldehydes or isatin derivatives according to the standard Knoevenagel condensation procedure (medium - acetic acid, the catalyst - fused sodium acetate). This approach has been used due to the established essential influence of the nature of ylidene moiety in position 5 of 4-thiazolidinone cycle on the anti-tumor activity [47-49] and allowed to obtain the group of titled 5-arylidene/isatinylidene substituted 2-(1,3,4-oxadiazol-2yl)iminothiazolidine-4-ones (compounds 5a-h and 6a-d) according to Scheme 1.

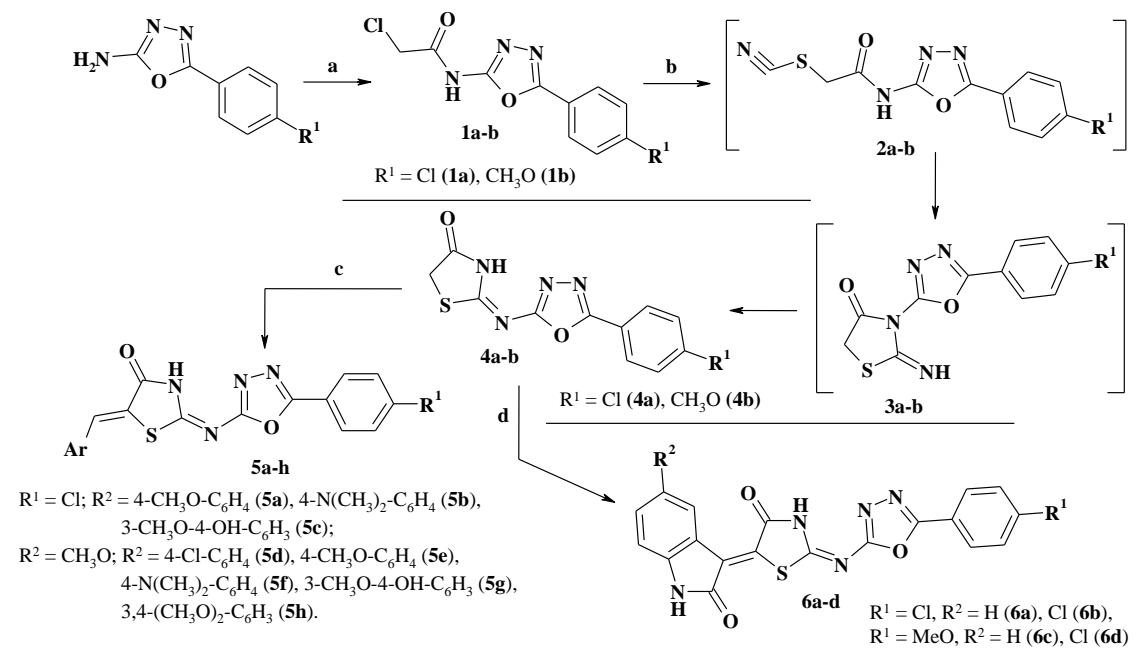

Scheme 1. Synthesis of 1,3,4-oxadiazol-2-yl substituted 5-arylidene/isatinylidene-2-iminothiazolidin-4-ones. Reagents, conditions and yields: (a) $\mathrm{ClCH}_{2} \mathrm{COCl},\left(\mathrm{C}_{2} \mathrm{H}_{5}\right)_{3} \mathrm{~N}$, dry dioxane, $90^{\circ} \mathrm{C}, 30 \mathrm{~min}, 89-92 \%$; (b) $\mathrm{NH}_{4} \mathrm{SCN}$, dry acetone, reflux 8h, 72-80\%; (c) Ar-CHO, AcONa, AcOH, reflux 4h, 67-75\%; (d) isatin or 5-chloroisatin, $\mathrm{AcONa}, \mathrm{AcOH}$, reflux 4h, 73-76\%.

Structures of the synthesized compounds were confirmed by ${ }^{1} \mathrm{H}$ NMR spectroscopy and elemental analysis. The characterization data of novel heterocyclic 1,3,4-oxadiazole substituted 2-imino-4-thiazolidones are presented in the experimental part. In the ${ }^{1} \mathrm{H}$ NMR spectra of the 5-unsubstituted derivatives, $4 \mathrm{a}-\mathrm{b}$, the protons of the cyclic methylene group appear as a singlet at $\delta \sim 4.08-4.12 \mathrm{ppm}$. The signal of a 5-methylidene proton $-\mathrm{CH}=$ for the target compounds 5a-h resonates as singlet with a higher chemical shift in the range of $\delta \sim 7.65-7.77 \mathrm{ppm}$, confirming a $Z$-configuration of the exocyclic $\mathrm{C}=\mathrm{C}$ bond at the 5-arylidene fragment [50-52]. The characteristic pattern of 5-unsubstituted isatin system (compounds 6a and 6c) consisting of two doublets $(\delta \sim 6.93-6.94$ and $\delta \sim 8.81 \mathrm{ppm}$, respectively) and two triplets $(\delta \sim 7.05-7.07$ and $\delta \sim 7.37 \mathrm{ppm}$ ) had been observed.

The proton's signal in position 4 of the isatin fragment for 5 -isatinylidene derivatives $6 \mathrm{a}-\mathrm{d}$ shifted towards a weak magnetic field and resonated as doublets $(6 \mathrm{a}, 6 \mathrm{c})$ or singlet $(6 \mathrm{~b}$, $6 \mathrm{~d}$ ) at $\delta \sim 8.81-9.01 \mathrm{ppm}$. This can be explained by the adjacent spatial arrangement of the $\mathrm{C}=\mathrm{O}$ group in position 4 of the thiazolidine cycle and confirms the $Z$-configuration of these compounds. NH proton's signal in position 1 of the isatin system appears as singlet or broad singlet in the range of $\delta \sim 10.99-11.32 \mathrm{ppm}$.

The synthesized 2-(1,3,4-oxadiazol-2-yl)-imino-4-thiazolidinones 4a-b and their 5aryl(isatin)ylidene derivatives $5 \mathrm{a}-\mathrm{h}$ and $6 \mathrm{a}-\mathrm{d}$ are characterized by prototropic amino-imino tautomerism. Their structures can be determined by analyzing $1 \mathrm{H}$ NMR spectral data, 
particularly by the chemical shift value of the endocyclic NH-proton signal for imino form or exocyclic for amino form which will be different. The NH proton in position 3 of thiazolidine cycle resonates as a singlet in the range of $\delta \sim 12.28-12.46 \mathrm{ppm}$ for $4 \mathrm{a}-\mathrm{b}$ or $\delta \sim 12.60-13.06$ ppm for 5a-h, 6a-d. This is more characteristic to the endocyclic lactam proton than the exocyclic imino one [53, 54] and suggests that the 1,3,4-oxadiazole substituted 4thiazolidinones in the dissolved state have an imino form exclusively. It was also confirmed the existence of imino form for 5-unsubstituted derivative $4 \mathrm{~b}$ in the solid-state based on the $\mathrm{X}$ ray data and described elsewhere [42].

\subsection{In vitro evaluation of the anti-cancer activity.}

The novel 1,3,4-oxadiazole substituted 2-imino-4-thiazolidinones 4b, 5a, 5d-h, 6b, and $6 \mathrm{~d}$ were selected by the National Cancer Institute (NCI) and evaluated at the single concentration of $10^{-5} \mathrm{M}$ towards a panel of the approximately sixty cancer cell lines. Primary anti-cancer assays were performed according to the Developmental Therapeutic Program protocol (www.dtp.nci.nih.gov) relative to the human tumor cell lines representing the nine different types of cancer diseases, including leukemia, melanoma, lung, colon, CNS, ovarian, renal, prostate, and breast cancers. The obtained results are reported as the cancer cell line growth percent (GP) and are shown in Table 1. The range of growth (\%) showed the lowest and the highest growth that was found among different cancer cell lines.

Table 1. Anti-cancer screening data of the tested compounds in 1-dose concentration $10^{-5} \mathrm{M}$.

\begin{tabular}{|c|c|c|c|c|}
\hline Compound & Mean growth, $\%$ & Range of growth, \% & The most sensitive cell lines & $\begin{array}{l}\text { Growth of the most } \\
\text { sensitive cell line, \% }\end{array}$ \\
\hline $4 \mathrm{~b}$ & 101.94 & $71.89 \div 126.45$ & $\begin{array}{l}\text { SNB-75 (CNS Cancer) } \\
\text { A498 (Renal Cancer) }\end{array}$ & $\begin{array}{l}71.89 \\
82.13 \\
\end{array}$ \\
\hline $5 \mathrm{a}$ & 57.82 & $16.02 \div 99.62$ & $\begin{array}{l}\text { MDA-MB-435 (Melanoma) } \\
\text { SF-295 (CNS Cancer) } \\
\text { SR (Leukemia) } \\
\text { NCI-H460 (NSC Lung Cancer) } \\
\text { K-562 (Leukemia) } \\
\text { CCRF-CEM (Leukemia) } \\
\text { MCF7 (Breast Cancer) } \\
\text { OVCAR-3 (Ovarian Cancer) } \\
\text { SK-MEL-5 (Melanoma) } \\
\end{array}$ & \begin{tabular}{|l|}
16.02 \\
29.18 \\
29.97 \\
30.67 \\
34.12 \\
34.60 \\
35.80 \\
38.20 \\
39.49 \\
\end{tabular} \\
\hline $5 \mathrm{~d}$ & 103.11 & $89.12 \div 128.14$ & UO-31 (Renal Cancer) & 89.12 \\
\hline $5 \mathrm{e}$ & 68.88 & $33.47 \div 124.95$ & $\begin{array}{l}\text { SF-295 (CNS Cancer) } \\
\text { HOP-62 (NSC Lung Cancer) } \\
\text { NCI-H460 (NSC Lung Cancer) } \\
\text { UACC-62 (Melanoma) } \\
\text { CCRF-CEM (Leukemia) }\end{array}$ & $\begin{array}{l}33.47 \\
36.29 \\
37.52 \\
40.40 \\
41.28 \\
\end{array}$ \\
\hline $5 f$ & 92.84 & $47.76 \div 129.37$ & $\begin{array}{l}\text { MDA-MB-435 (Melanoma) } \\
\text { SNB-75 (CNS Cancer) } \\
\text { SF-295 (CNS Cancer) }\end{array}$ & $\begin{array}{l}47.76 \\
60.43 \\
69.84 \\
\end{array}$ \\
\hline $5 \mathrm{~g}$ & 104.69 & $89.15 \div 134.90$ & MCF7 (Breast Cancer) & 89.15 \\
\hline $5 \mathrm{~h}$ & 63.23 & $28.31 \div 102.10$ & $\begin{array}{l}\text { SF-295 (CNS Cancer) } \\
\text { NCI-H460 (NSC Lung Cancer) } \\
\text { NCI/ADR-RES (Ovarian Cancer) } \\
\text { HCT-116 (Colon Cancer) } \\
\text { HCT-15 (Colon Cancer) } \\
\text { UACC-62 (Melanoma) }\end{array}$ & $\begin{array}{l}28.31 \\
28.90 \\
31.26 \\
36.71 \\
37.37 \\
41.53 \\
\end{array}$ \\
\hline $6 \mathrm{~b}$ & 103.20 & $82.20 \div 122.75$ & UO-31 (Renal Cancer) & 82.20 \\
\hline $6 \mathrm{~d}$ & 98.98 & $82.24 \div 139.07$ & MDA-MB-468 (Breast Cancer) & 82.24 \\
\hline
\end{tabular}

The tested 5-aryl(isatin)ylidene-2-(5-aryl-[1,3,4]-oxadiazol-2-ylimino)thiazolidin-4ones displayed moderate $(5 \mathrm{a}, 5 \mathrm{e}, 5 \mathrm{~h})$ or low $(4 \mathrm{~b}, 5 \mathrm{~d}, 5 \mathrm{f}, 5 \mathrm{~g}, 6 \mathrm{~b}, 6 \mathrm{~d})$ activity in the in vitro screening on the cancer cell lines. However a selective influence of some compounds on several cancer cell lines was observed (Table 1). In particular, some compounds were highly active 
against leukemia SR cell line (5a, GP $=29.97 \%)$, NSC lung cancer HOP-62 (5e, GP $=36.29 \%)$ and NCI-H460 (5e, GP $=37.52 \% ; 5 \mathrm{~h}, \mathrm{GP}=37.52 \%)$ cell lines, CNS cancer SF-295 cell line $(5 \mathrm{a}, \mathrm{GP}=29.18 \% ; 5 \mathrm{e}, \mathrm{GP}=33.47 \%$; 5h, GP $=28.31 \%)$, melanoma MDA-MB-435 cell line $(5 \mathrm{a}, \mathrm{GP}=16.02 \%)$ and ovarian cancer $\mathrm{NCI} / \mathrm{ADR}-\mathrm{RES}$ cell line $(5 \mathrm{~h}, \mathrm{GP}=31,26 \%)$. In addition, the average group activity of this compounds is higher than isatin, oxadiazole and 4thiazolidinone based conjugates described by us previously [55].

Finally, compound 5a possessed considerable activity against all human tumor cell lines and was selected for advanced assay against a panel of tumor cell lines at 10-fold dilutions of five concentrations $(100 \mu \mathrm{M}, 10 \mu \mathrm{M}, 1 \mu \mathrm{M}, 0.1 \mu \mathrm{M}$, and $0.01 \mu \mathrm{M})$ [51-54]. The percentage of growth was evaluated spectrophotometrically versus controls not treated with test agents. The 48-h continuous drug exposure protocol followed, and sulforhodamine B protein assay was used to estimate cell viability or growth.

Based on the cytotoxicity assays, three anti-tumor activity dose-response parameters were calculated for experimental agents against each cell line: GI50 - molar concentration of the compound that inhibits 50\% net cell growth; TGI - molar concentration of the compound leading to total inhibition; and $\mathrm{LC}_{50}$ - molar concentration of the compound leading to 50\% net cell death. Furthermore, mean graph midpoints (MG_MID) were calculated for mentioned parameters. This made it possible to demonstrate an average activity parameter over all cell lines for tested compounds. For the calculation of the MG_MID, the insensitive cell lines were included with the highest tested concentration (Table 2).

Table 2. The influence of compound $5 \mathrm{a}$ on the growth of individual tumor cell lines $\left(\log \mathrm{GI}_{50} \leq-5.00\right)$.

\begin{tabular}{|c|c|c|c|c|c|c|c|}
\hline Disease & Cell line & $\log G I_{50}$ & Log TGI & Disease & Cell line & $\log \mathrm{GI}_{50}$ & Log TGI \\
\hline \multirow[t]{5}{*}{ Leukemia } & CCRF-CEM & -5.29 & -4.26 & \multirow[t]{6}{*}{ Melanoma } & M14 & -5.21 & -4.15 \\
\hline & K-562 & -5.34 & -4.63 & & MDA-MB-435 & -5.55 & $>-4.00$ \\
\hline & MOLT-4 & -5.04 & $>-4.00$ & & SK-MEL-2 & -5.13 & $>-4.00$ \\
\hline & RPMI-8226 & -5.11 & $>-4.00$ & & SK-MEL-28 & -5.01 & $>-4.00$ \\
\hline & SR & -5.36 & $>-4.00$ & & SK-MEL-5 & -5.34 & $>-4.00$ \\
\hline \multirow{7}{*}{$\begin{array}{l}\text { Non-Small } \\
\text { Cell Lung } \\
\text { Cancer }\end{array}$} & EKVX & -5.35 & $>-4.00$ & & UACC-62 & -5.20 & $>-4.00$ \\
\hline & HOP-62 & -5.17 & $>-4.00$ & \multirow[t]{4}{*}{ Ovarian Cancer } & IGROV1 & -5.28 & -4.05 \\
\hline & NCI-H226 & -5.02 & $>-4.00$ & & OVCAR-3 & -5.40 & -4.54 \\
\hline & NCI-H23 & -5.26 & $>-4.00$ & & OVCAR-4 & -6.01 & $>-4.00$ \\
\hline & NCI-H322M & -5.20 & $>-4.00$ & & NCI/ADR-RES & -5.53 & -4.76 \\
\hline & NCI-H460 & -5.47 & $>-4.00$ & \multirow[t]{6}{*}{ Renal Cancer } & $786-0$ & -5.14 & $>-4.00$ \\
\hline & NCI-H522 & -5.27 & $>-4.00$ & & A498 & -5.59 & -4.53 \\
\hline \multirow[t]{5}{*}{ Colon Cancer } & HCT-116 & -5.37 & -4.45 & & $\mathrm{ACHN}$ & -5.18 & $>-4.00$ \\
\hline & HCT-15 & -5.39 & $>-4.00$ & & CAKI-1 & -5.99 & -4.78 \\
\hline & HT29 & -5.12 & $>-4.00$ & & RXF 393 & -5.02 & $>-4.00$ \\
\hline & KM12 & -5.32 & $>-4.00$ & & UO-31 & -6.37 & $>-4.00$ \\
\hline & SW-620 & -5.34 & $>-4.00$ & Prostate Cancer & PC-3 & -5.20 & $>-4.00$ \\
\hline \multirow[t]{6}{*}{ CNS Cancer } & SF-268 & -5.13 & $>-4.00$ & \multirow[t]{4}{*}{ Breast Cancer } & MCF7 & -5.17 & $>-4.00$ \\
\hline & SF-295 & -5.59 & -4.68 & & HS 578T & -5.15 & $>-4.00$ \\
\hline & SF-539 & -5.08 & $>-4.00$ & & BT-549 & -5.31 & -4.21 \\
\hline & SNB-19 & -5.06 & $>-4.00$ & & MDA-MB-468 & -5.34 & -4.36 \\
\hline & SNB-75 & -5.20 & $>-4.00$ & & & & \\
\hline & U251 & -5.19 & $>-4.00$ & MG_MID & & -5.19 & -4.09 \\
\hline
\end{tabular}

Compound 5a showed a broad spectrum of growth inhibition activity against human tumor cells with average $\operatorname{lgGI} 50$ and $\lg$ TGI values of -5.19 and -4.09 , respectively (Table 2). It was established that the compound 5a caused the growth inhibition by $50 \%$ of tumor cells at a concentration less than $10^{-4} \mathrm{M}\left(\log \mathrm{GI}_{50}<-4.00\right)$ on all 58 cancer cell lines and exhibited a total growth inhibition $(\log$ TGI $<-4.00)$ on 12 of them.

Selectivity pattern analysis of cell lines by disease origin can affirm the selectivity of 5a against renal cancer cell lines (Figure 2), with the logGI50 varying from -6.37 to -5.02 (Table 
2 ). The compound 5a was found to be a highly active growth inhibitor of the ovarian cancer OVCAR-4 $\left(\log \mathrm{II}_{50}=-6.01\right)$ cell line and renal cancer CAKI-1 and UO-31 $\left(\log \mathrm{GI}_{50}=-6.01\right.$ and -6.37 , respectively) cell lines.

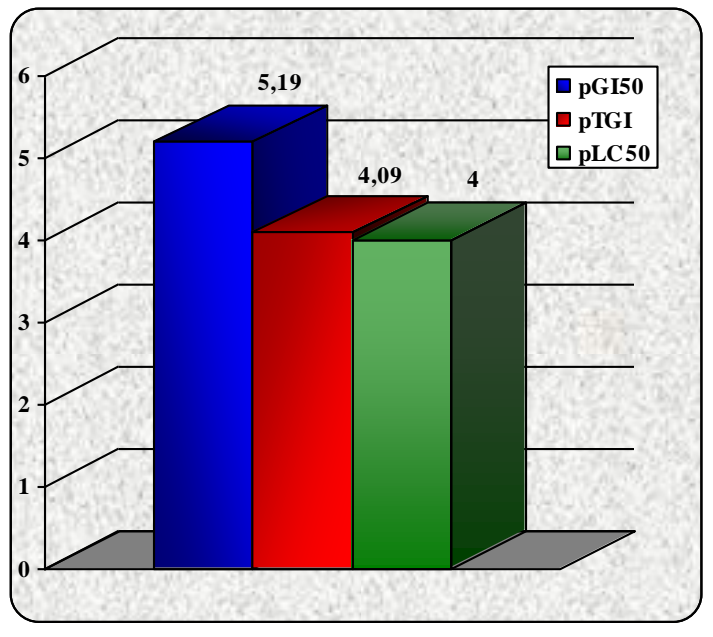

(a)

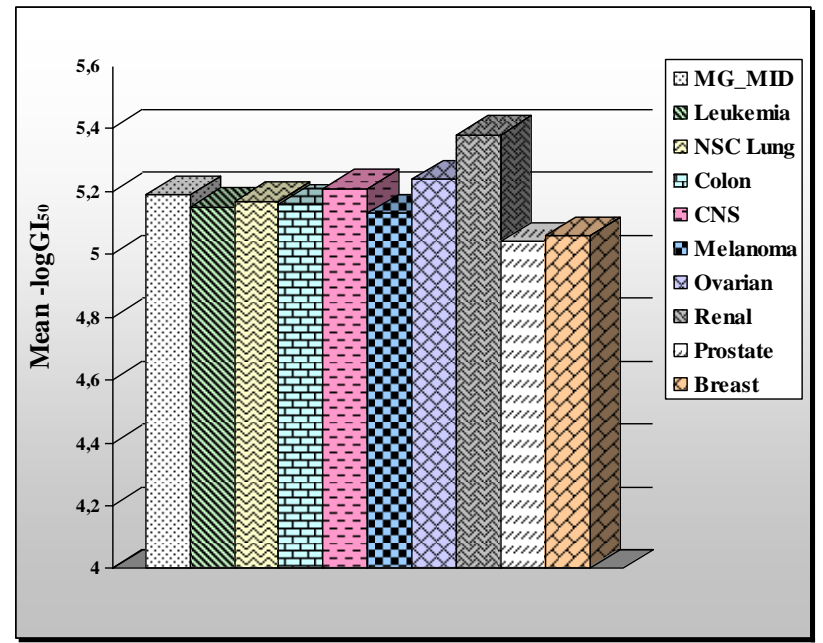

(b)

Figure 2. Average values of $\mathrm{pGI}_{50}$, pTGI, and $\mathrm{pLC}_{50}$ parameters (a) and anti-cancer activity pattern (b) of the most active compound 5a.

To establish a possible mechanism of anti-tumor activity of highly active compound 5a, a COMPARE analysis was performed [56, 57]. The experimental values of the GI50 parameters of the new compound with standard anti-cancer agents have been compared. The application of COMPARE algorithm could provide preliminary information regarding growth inhibition and cell killing mechanism. However, obtained correlation coefficients $(r)$ at $\mathrm{GI}_{50}$ level didn't distinguish a cytotoxicity mechanism of 5a with high probability. Nevertheless compound 5a showed moderate correlations with rapamycin (NSC: S226080, mTOR (mammalian target of rapamycin) inhibitor, $r=0.468$ ) [58] and cisplatin (NSC: S119875, transcription and/or DNA replication mechanisms inhibitor, $r=0.421$ ) [59].

The SAR study revealed that: (1) anti-cancer activity of compounds $5 \mathrm{a}, 5 \mathrm{~d}-\mathrm{h}, 6 \mathrm{~b}$, and $6 \mathrm{~d}$ is sensitive to the nature of the substituent at position 5 of 4-thiazolidinone cycle; (2) introduction of a methoxy group at position 4 (compounds 5a, 5e) or 3 and 4 (compound 5h) of the benzylidene fragment significantly enhanced anti-tumor potency compared to their synthetic precursor $4 b$; (3) replacement of the 4-methoxy group (5e) at the phenyl ring in the position 5 of 1,3,4-oxadiazole cycle with chlorine substituent (5a) leads to a slight increase of the antimitotic effect.

\section{Conclusions}

In the present paper, the synthesis and characteristics of fourteen new 5-ylidene-2iminothiazolidine-4-ones containing 1,3,4-oxadiazole moiety were described. Nine synthesized compounds were tested, and three of them $(5 \mathrm{a}, 5 \mathrm{e}, 5 \mathrm{~h})$ displayed moderate antitumor activity against leukemia, melanoma, lung, colon, CNS, ovarian, renal, prostate, and breast cancer cell lines. It was found that the introduction of the methoxy group at positions 4 or 3 and 4 of the benzylidene fragment significantly enhanced the anti-tumor action of the compounds.

In conclusion, the preliminary results allowed us to identify the most active compound 5a, which could be a perspective anti-tumor agent (average $\log \mathrm{GI}_{50}$ and $\log$ TGI values -5.19 
and -4.09, respectively). Furthermore, 2-[5-(4-chlorophenyl)-[1,3,4]oxadiazol-2-ylimino]-5(4-methoxybenzylidene)thiazolidin-4-one (5a) showed a pronounced selective potency against ovarian cancer OVCAR-4 $\left(\log \mathrm{GI}_{50}=-6.01\right)$ cell line and renal cancer CAKI-1 and UO-31 $\left(\log \mathrm{GI}_{50}=-6.01\right.$ and -6.37 , respectively) cell lines. These results can be considered background for rational design and further in-depth studies of 1,3,4-oxadiazole substituted 2-imino-4thiazolidinones as potential anti-tumor drugs.

\section{Funding}

This research received no external funding.

\section{Acknowledgments}

We are grateful Drug Synthesis and Chemistry Branch, National Cancer Institute, Bethesda, $\mathrm{MD}$, USA, for in vitro evaluation of the anti-cancer activity.

\section{Conflicts of Interest}

The authors declare no conflict of interest.

\section{References}

1. Jain, V.S.; Vora, D.K.; Ramaa, C.S. Thiazolidine-2,4-diones: Progress towards multifarious applications. Bioorg. Med. Chem. 2013, 21, 1599-1620, https://doi.org/10.1016/j.bmc.2013.01.029.

2. Tripathi, A.C.; Gupta, S.J.; Fatima, G.N.; Sonar, P.K.; Verma, A.; Saraf, S.K. 4-Thiazolidinones: The advances continue... Eur. J. Med. Chem. 2014, 72, 52-77, https://doi.org/10.1016/j.ejmech.2013.11.017.

3. Nirwan, S.; Chahal, V.; Kakkar, R. Thiazolidinones: Synthesis, reactivity, and their biological applications. J. Het. Chem. 2019, 56, 1239-1253, https://doi.org/10.1002/jhet.3514.

4. Agrawal, N. Synthetic and therapeutic potential of 4-thiazolidinone and its analogs. Curr. Chem. Lett. 2021, 10, 119-138, https://doi.org/10.5267/j.ccl.2020.11.002.

5. Revelant, G.; Huber-Villaume, S.; Dunand, S.; Kirsch, G.; Schohn, H.; Hesse, S. Synthesis and biological evaluation of novel 2-heteroarylimino-1,3-thiazolidin-4-ones as potential anti-tumor agents. Eur. J. Med. Chem. 2015, 94, 102-112, https://doi.org/10.1016/j.ejmech.2015.02.053.

6. Singh, R.P.; Aziz, M.N.; Gout, D.; Fayad, W.; EL-Manawaty, M.A.; Lovely, C.J. Novel thiazolidines: Synthesis, antiproliferative properties and 2D-QSAR studies. Bioorg. Med. Chem. 2019, 27, https://doi.org/10.1016/j.bmc.2019.115047.

7. Türe, A.; Ergül, M.; Ergül, M.; Altun, A.; Küçükgüzel, I. Design, synthesis, and anticancer activity of novel 4-thiazolidinone-phenylaminopyrimidine hybrids. Mol. Divers. 2020, https://doi.org/10.1007/s11030-02010087-1.

8. Metwally, N.H.; Radwan, I.T.; El-Serwy, W.S.; Mohamed, M.A. Design, synthesis, DNA assessment and molecular docking study of novel 2-(pyridin-2-ylimino)thiazolidin-4-one derivatives as potent antifungal agents. Bioorg. Chem. 2019, 84, 456-467, https://doi.org/10.1016/j.bioorg.2018.11.050

9. Omar, K.; Geronikaki, A.; Zoumpoulakis, P.; Camoutsis, C.; Soković, M.; Ćirić, A.; Glamočlija, J. Novel 4thiazolidinone derivatives as potential antifungal and antibacterial drugs. Bioorg. Med. Chem. 2010, 18, 426432, https://doi.org/10.1016/j.bmc.2009.10.041.

10. Hammad, S.G.; El-Gazzar, M.G.; Abutaleb, N.S.; Li, D.; Ramming, I.; Shekhar, A.; Abdel-Halim, M.; Elrazaz, E.Z.; Seleem, M.N.; Bilitewski, U.; Abouzid, K.A.M.; El-Hossary, E.M. Synthesis and antimicrobial evaluation of new halogenated 1,3-thiazolidin-4-ones. Bioorg. Chem. 2020, 95, https://doi.org/10.1016/j.bioorg.2019.103517

11. Abdellatif, K.R.A.; Abdelgawad, M.A.; Elshemy, H.A.H.; Alsayed, S.S.R. Design, synthesis and biological screening of new 4-thiazolidinone derivatives with promising COX-2 selectivity, anti-inflammatory activity and gastric safety profile. Bioorg. Chem. 2016, 64, 1-12, https://doi.org/10.1016/j.bioorg.2015.11.001.

12. Kotte, D.; Gullapelli, K.; Gavaji, B.; Merugu, R.; Maroju, R.; Patwari, M. An efficient synthesis, anti inflammatory activity and molecular docking studies of new triazinanes and iminothiazolidinones. Res. J. Pharm. Tech. 2020, 13, 4743-4750, https://doi.org/10.5958/0974-360X.2020.00836.7

13. Chawla, P.; Kalra, S.; Kumr, R.; Singh, R.; Saraf, S.K. Novel 2-(substituted phenyl imino)-5-benzylidene4-thiazolidinones as possible non-ulcerogenic tri-action drug candidates: synthesis, characterization, biological evaluation and docking studies. Med. Chem. Res. 2019, 28, 340-359, https://doi.org/10.1007/s00044-018-02288-z. 
14. Ansari, M.F.; Inam, A.; Ahmad, K.; Fatima, S.; Agarwal, S.M.; Azam, A. Synthesis of metronidazole based thiazolidinone analogs as promising antiamoebic agents. Bioorg. Med. Chem. Lett. 2020, 30, https://doi.org/10.1016/j.bmcl.2020.127549.

15. Geronikaki, A.; Eleftheriou, P.; Vicini, P.; Alam, I.; Dixit, A.; Saxena, A.K. 2Thiazolylimino/Heteroarylimino-5-arylidene-4-thiazolidinones as new agents with SHP-2 inhibitory action. J. Med. Chem. 2008, 51, 5221-5228, https://doi.org/10.1021/jm8004306.

16. Richardson, C.M.; Nunns, C.L.; Williamson, D.S.; Parratt, M.J.; Dokurno, P.; Howes, R.; Borgognoni, J.; Drysdale, M.J.; Finch, H.; Hubbard, R.E.; Jackson, P.S.; Kierstan, P.; Lentzen, G.; Moore, J.D.; Murray, J.B.; Simmonite, H.; Surgenor, A.E.; Torrance, C.J. Discovery of a potent CDK2 inhibitor with a novel binding mode, using virtual screening and initial, structure-guided lead scoping. Bioorg. Med. Chem. Lett. 2007, 17, 3880-3885, https://doi.org/10.1016/j.bmcl.2007.04.110.

17. Park, H.; Jung, S.-K.; Jeong, D.G.; Ryu, S.E.; Kim, S.J. Discovery of novel PRL-3 inhibitors based on the structure-based virtual screening. Bioorg. Med. Chem. Lett. 2008, 18, 2250-2255, https://doi.org/10.1016/j.bmcl.2008.03.013.

18. Sigalapalli, D.K.; Pooladanda, V.; Kadagathur, M.; Guggilapu, S.D.; Uppu J.L.; Godugu, C.; Bathini, N.B.; Tangellamudi, N.D. Novel chromenyl-based 2-iminothiazolidin-4-one derivatives as tubulin polymerization inhibitors: Design, synthesis, biological evaluation and molecular modelling studies. J. Mol. Struct. 2021, 1225, https://doi.org/10.1016/j.molstruc.2020.128847

19. Shingare, R.M.; Patil, Y.S.; Sangshetty, J.N.; Patil, R.B.; Rajani, D.P.; Madje, B.R. Synthesis, biological evaluation and docking study of some novel isoxazole clubbed 1,3,4-oxadiazoles derivatives. Med Chem Res, 2018, 27,1283-1291, https://doi.org/10.1007/s00044-018-2148-2.

20. Çevik, U.A.; Osmaniye, D, Çavuşoğlu, B.K.; Sağlik, B.N.; Levent, S.; Ilgin, S.; Can, N.Ö.; Özkay, Y.; Kaplancikli, Z.A. Synthesis of novel benzimidazole-oxadiazole derivatives as potent anticancer activity. Med. Chem. Res. 2019, 28, 2252-2261, https://doi.org/10.1007/s00044-019-02451-0.

21. Rohand, T.; Ramli, Y.; Baruah, M.; Budka, J.; Das, A.M. Synthesis, structure elucidation and antimicrobial properties of new bis-1,3,4-oxadiazole derivatives. Pharm Chem J. 2019, 53, 150-154, https://doi.org/10.1007/s11094-019-01969-2.

22. Nimbalkar, U.D.; Tupe, S.G.; Vazques, J.A.S.; Khan, F.A.K.; Sangshetty, J.N.; Nikalje, A.P.G. Ultrasoundand molecular sieves-assisted synthesis, molecular docking and antifungal evaluation of 5-(4-(benzyloxy)substituted phenyl)-3-((phenylamino)methyl)-1,3,4-oxadiazole-2(3H)-thiones. Molecules 2016, 21, https://doi.org/10.3390/molecules21050484.

23. Albratty, M.; El-Sharkawy, K.A.; Alhazmi, H.A. Synthesis and evaluation of some new 1,3,4-oxadiazoles bearing thiophene, thiazole, coumarin, pyridine and pyridazine derivatives as antiviral agents. Acta Pharm. 2019, 69, 261-276, https://doi.org/10.2478/acph-2019-001508.

24. Abdelazeem, A.H.; El-Din, A.G.S.; El-Saadi, M.T.; El-Moghazy, S.M.; Amin, N.H. Design, synthesis and biological evaluation of diarylpyrazole/triazole bearing 1,3,4-oxadiazole moiety as COXs inhibitors endowed with potential anti-inflammatory and analgesic activities. Res. J. Pharm. Tech. 2020, 13, 42554262, https://doi.org/10.5958/0974-360X.2020.00751.9.

25. Tantray, M.A.; Khan, I.; Hamid, H.; Alam, M.S.; Dhulap, A.; Kalam, A. Synthesis of benzimidazole-linked1,3,4-oxadiazole carboxamides as GSK-3 $\beta$ inhibitors with in vivo antidepressant activity. Bioorg Chem. 2018, 77, 393-401, https://doi.org/10.1016/j.bioorg.2018.01.040.

26. De Oliveira, C.S.; Lira, B.F.; Barbosa-Filho, J.M.; Lorenzo, J.G.F.; de Athayde-Filho, P.F. Synthetic approaches and pharmacological activity of 1,3,4-oxadiazoles: A review of the literature from 2000-2012. Molecules 2012, 17, 10192-10231, https://doi.org/10.3390/molecules170910192.

27. Zarghi, A.; Hajimahdi, Z. Substituted oxadiazoles: A patent review (2010-2012). Expert Opin. Ther. Patents 2013, 23, 1209-1232, https://doi.org/10.1517/13543776.2013.797409.

28. Salahuddin; Mazumder, A.; Yar, M.S.; Mazumder, R.; Chakraborthy, G.S.; Ahsan, M.J.; Rahman, M.U. Updates on synthesis and biological activities of 1,3,4-oxadiazole: A review. Synth. Commun. 2017, 47, 1805-1847, https://doi.org/10.1080/00397911.2017.1360911.

29. Lelyukh, M.; Demchuk, I.; Harkov, S.; Chaban, T.; Drapak, I.; Chaban, I.; Shelepeten, L.; Matiychuk, V. A review on synthetic routes for obtaining of 2,5-disubstituted 1,3,4-oxadiazoles via cyclodehydration and oxidative cyclization reactions. Biointerface Res. Appl. Chem. 2020, 10, 5960-5971, https://doi.org/10.33263/BRIAC104.960971.

30. Lelyukh, M.; Martynets, M.; Kalytovska, M.; Drapak, I.; Harkov, S.; Chaban, T.; Chaban, I.; Matiychuk, V. Approaches for synthesis and chemical modification of non-condensed heterocyclic systems based on 1,3,4oxadiazole ring and their biological activity: A review. J. Appl. Pharm. Sci. 2020, 10, 151-165, https://doi.org/10.7324/JAPS.2020.1010016.

31. Khan, I.; Ibrar, A.; Abbas, N. Oxadiazoles as privileged motifs for promising anti-cancer leads: Recent advances and future prospects. Arch. Pharm. 2013, 346, 1-20, https://doi.org/10.1002/ardp.201300231.

32. Vaidya, A.; Pathak, D.; Shah, K. 1,3,4-Oxadiazole and its derivatives: A review on recent progress in anticancer activities. Chem. Biol. Drug Des. 2021, 97, 572-591, https://doi.org/10.1111/cbdd.13795. 
33. Zhang, Y.-B.; Wang, X.-L.; Liu, W.; Yang, Y.-S.; Tang, J.-F.; Zhu, H.-L. Design, synthesis and biological evaluation of heterocyclic azoles derivatives containing pyrazine moiety as potential telomerase inhibitors. Bioorg. Med. Chem. 2012, 20, 6356-6365, https://doi.org/10.1016/j.bmc.2012.08.059.

34. Zhang, S.; Luo, Y.; He, L.-Q.; Liu, Z.-J.; Jiang, A.-Q.; Yang, Y.-H.; Zhu, H.-L. Synthesis, biological evaluation, and molecular docking studies of novel 1,3,4-oxadiazole derivatives possesing benzotriazole moiety as FAK inhibitors with anti-cancer activity. Bioorg. Med. Chem. 2013, 21, 3723-3729, https://doi.org/10.1016/j.bmc.2013.04.043.

35. Rajak, H.; Agarawal, A.; Parmar, P.; Thakur, B.S.; Veerasamy, R.; Sharma, P.C.; Kharya, M.D. 2,5Disubstituted-1,3,4-oxadiazoles/thiadiazole as surface recognition moiety: Design and synthesis of novel hydroxamic acid based histone deacetylase inhibitors. Bioor. Med. Chem. Lett. 2011, 21, 5735-5738, https://doi.org/10.1016/j.bmcl.2011.08.022.

36. Kamal, A.; Dastagiri, D.; Ramaiah, M.J.; Bharathi, E.V.; Reddy, J.S.; Balakishan, G.; Sarma, P.; Pushpavalli, S.N.C.V.L.; Pal-Bhadra, M.; Juvekar, A.; Sen, S.; Zingde, S. Synthesis, anti-cancer activity and mitochondrial mediated apoptosis inducing ability of 2,5-diaryloxadiazole-pyrrolobenzodiazepine conjugates. Bioorg. Med. Chem. 2010, 18, 6666-6677, https://doi.org/10.1016/j.bmc.2010.07.067.

37. Bondock, S.; Adel, S.; Etman, H.A.; Badria, F.A. Synthesis and anti-tumor evaluation of some new 1,3,4oxadiazole-based heterocycles. Eur. J. Med. Chem. 2012, 48, 192-199, https://doi.org/10.1016/j.ejmech.2011.12.013.

38. Lelyukh, M.; Adamchuk, S.; Harkov, S.; Chaban, I.; Demchuk, I.; Shelepeten, L.; Chaban, T. Synthetic approaches, chemical modification and biological activity of non-condensed 1,3,4-thiadiazole derivatives: A review. Pharmacia, 2018, 65, 72-88.

39. Bhutani, R.; Pathak, D.P.; Kapoor, G.; Husain, A.; Iqbal, Md.A. Novel hybrids of benzothiazole-1,3,4oxadiazole-4-thiazolidinone: Synthesis, in silico ADME study, molecular docking and in vivo anti-diabetic assessment. Bioorg. Chem. 2019, 83, 6-19, https://doi.org/10.1016/j.bioorg.2018.10.025.

40. Omar, Y.M.; Abdel-Moty, S.G.; Abdu-Allah, H.H.M. Further insight into the dual COX-2 and 15-LOX antiinlammatory activity of 1,3,4-thiadiazole-thiazolidinone hybrids: The contribution of the substituents at 5th positions is size dependent. Bioorg. Chem. 2020, 97, https://doi.org/10.1016/j.bioorg.2020.103657.

41. Rajak, H.; Kharya, M.D.; Mishra, P. Synthesis and local anesthetic activity of some novel $N$-[5-(4substituted)phenyl-1,3,4-oxadiazol-2-yl]-2-(substituted)-acetamides. Arch. Pharm. 2008, 341, 247-261, https://doi.org/10.1002/ardp.200700146.

42. Kaminskyy, D.; den Hartog, G.J.M.; Wojtyra, M.; Lelyukh, M.; Gzella, A.; Bast, A.; Lesyk, R. Antifibrotic and anti-cancer action of 5-ene amino/iminothiazolidinones. Eur. J. Med. Chem. 2016, 112, 180-195, https://doi.org/10.1016/j.ejmech.2016.02.011.

43. Monks, A.; Scudiero, D.; Skehan, P.; Shoemaker, R.; Paull, K.; Vistica, D.; Hose, C.; Langley, J.; Cronise, P.; Vaigro-Wolff, A.; Gray-Goodrich, M.; Campbell, H.; Mayo, J.; Boyd, M. Feasibility of a high-flux anticancer drug screen using a diverse panel of cultured human tumor cell lines. J. Nat. Cancer Inst. 1991, 83, 757-766, https://doi.org/10.1093/jnci/83.11.757.

44. Boyd, M.R.; Paull, K.D. Some practical considerations and applications of the national cancer institute in vitro anti-cancer drug discovery screen. Drug Dev. Res. 1995, 34, 91-109, https://doi.org/10.1002/ddr.430340203.

45. Boyd, M.R.; Teicher, B.A. Cancer Drug Discovery and Development. Humana Press 1997, 2, 23-43, https://doi.org/10.7124/bc.000971.

46. Shoemaker, R.H. The NCI60 human tumour cell line anti-cancer drug screen. Nat. Rev. Cancer 2006, 6, 813-823, https://doi.org/10.1038/nrc1951.

47. Havrylyuk, D.; Mosula, L.; Zimenkovsky, B.; Vasylenko, O.; Gzella, A.; Lesyk, R. Synthesis and anti-cancer activity evaluation of 4-thiazolidinones containing benzothiazole moiety. Eur. J. Med. Chem. 2010, 45, 5012-5021, https://doi.org/10.1016/j.ejmech.2010.08.008.

48. Patil, V.; Tilekar, K.; Mehendake-Munj, S.; Mohan, R.; Ramaa, C.S. Synthesis and primary cytotoxicity evaluation of new 5-benzylidene-2,4-thiazolidinedione derivatives. Eur. J. Med. Chem. 2010, 45, 45394544, https://doi.org/10.1016/j.ejmech.2010.07.014.

49. Abumelha, H.M.A.; Saeed, A. Synthesis of some 5-arylidene-2-(4-acetamidophenylimino)-thiazolidin-4one derivatives and exploring their breast anti-cancer activity. J. Het. Chem. 2020, 57, 1816-1824, https://doi.org/10.1002/jhet.3906.

50. Popov-Pergal, K.; Cekovic, Z.; Pergal, M. Condensation of 2,4-dioxotetrahydro-1,3-thiazole with aromatic aldehydes. J. Gen. Chem. USSR. 1991, 61, 1958-1962.

51. Bruno, G.; Costantino, L.; Curinga, C.; Maccari, R.; Monforte, F.; Nicolo, F.; Ottana, R.; Vigorita, M.G. Synthesis and aldose reductase inhibitory activity of 5-arylidene-2,4-thiazolidinediones. Bioorg. Med. Chem. 2002, 10, 1077-1084, https://doi.org/10.1016/S0968-0896(01)00366-2.

52. Vicini, P.; Geronikaki, A.; Incerti, M.; Zani, F.; Dearden, J.; Hewitt, M. 2-Heteroarylimino-5-benzylidene4-thiazolidinones analogues of 2-thiazolylimino-5-benzylidene-4-thiazolidinones with antimicrobial activity: Synthesis and structure-activity relationship. Bioorg. Med. Chem. 2008, 16, 3714-3724, https://doi.org/10.1016/j.bmc.2008.02.001. 
53. Bacchi, A.; Carcelli, M.; Pelizzi, G.; Vicini, P. Investigation on the amidine systems in amidinobenzisothiazole derivatives. Arch. Pharm. Chem. Life Sci. 1995, 328, 217-221, https://doi.org/10.1002/ardp.19953280303.

54. Vicini, P.; Geronikaki, A.; Anastasia, K.; Incerti, M.; Zani, F. Synthesis and antimicrobial activity of novel 2-thiazolylimino-5-arylidene-4-thiazolidinones. Bioorg. Med. Chem. 2006, 14, 3859-3864, https://doi.org/10.1016/j.bmc.2006.01.043.

55. Lelyukh, M.; Havrylyuk, D.; Lesyk, R. Synthesis and anti-cancer activity of isatin, oxadiazole and 4thiazolidinone based conjugates. Chem. Chem. Technol. 2015, 9, 29-36, https://doi.org/10.23939/chcht09.01.029.

56. Paull, K.D.; Shoemaker, R.H.; Hodes, L.; Monks, A.; Scudiero, D.A.; Rubinstein, L.; Plowman, J.; Boyd, M.R. Display and analysis of patterns of differential activity of drugs against human tumor cell lines: Development of mean graph and COMPARE algorithm. J. Nat. Cancer Inst. 1989, 81, 1088-1092, https://doi.org/10.1093/jnci/81.14.1088.

57. Zaharevitz, D.W.; Holbeck, S.L.; Bowerman, C.; Svetlic, P.A. COMPARE: A web accessible tool for investigating mechanisms of cell growth inhibition. J. Mol. Graph. Model. 2002, 20, 297-303, https://doi.org/10.1016/S1093-3263(01)00126-7.

58. Law, B.K. Rapamycin: An anti-cancer immunosuppressant? Crit. Rev. Oncol. Hematol. 2005, 56, 47-60, https://doi.org/10.1016/j.critrevonc.2004.09.009.

59. Fuertes, M.A.; Castilla, J.; Alonso, C.; Perez, J.M. Cisplatin biochemical mechanism of action: From cytotoxicity to induction of cell death through interconnections between apoptotic and necrotic pathways. Curr. Med. Chem. 2003, 10, 257-266, https://doi.org/10.2174/0929867033368484. 